\title{
Effect of bio-stimulants foliar applications on growth, yield, and product quality of two Cassava cultivars
}

\author{
Nagwa M. K. Hassan', Neama M. Marzouk', Zakaria F. Fawzy ${ }^{1}$ and Said A. Saleh ${ }^{2 *}$
}

\begin{abstract}
Background: Cassava is a major staple food crop for the people in tropical and sub-tropical areas, a non-traditional vegetable root crop in Egypt. It has important industrial raw materials for the production of starch, alcohol, pharmaceuticals, and livestock feed. The current study is evaluating two cassava cultivars: American and Brazilian types under three bio-stimulants: glutamine, lysine, and active dry yeast, as foliar applications. Vegetative growth characters, tuber yield, and its quality as well as chemical contents of cassava tubers were evaluated.

Results: The results showed that American cassava cultivar recorded the highest vegetative growth characters (plant height, leaves number, main stems, lateral branches, leaf area, and chlorophyll content), tuber yield (number and weight), and tuber quality (length, diameter, dry matter, and tubers-shoots ratio) as well as chemical composition (starch, total carbohydrates, N, P, and K). The foliar application of glutamine at the rate of $200 \mathrm{mg} / \mathrm{L}$ increased vegetative growth characters and tuber yield as well as tuber quality and improved chemical contents of cassava tubers. On the contrary, the lowest values of cassava growth and its productivity as well as chemical composition were associated to Brazilian cultivar when foliar sprayed by yeast at the concentration of $2 \mathrm{~g} / \mathrm{L}$.

Conclusion: From this study, it could be concluded that American type of cassava is the most suitable under Egyptian conditions, which ranked the first in all vegetative growth characters, tuber yield, tuber quality, and chemical composition, with foliar sprayed by glutamine at the rate of $200 \mathrm{mg} / \mathrm{L}$.
\end{abstract}

Keywords: Cassava, Cultivars, Bio-stimulants, Yield, Quality

\section{Background}

Cassava is a carbohydrate food source for people in the tropical and sub-tropical areas (FAO 2004; Abdullahi et al. 2014). The storage roots of cassava are the most important parts due to its contents of $80 \%$ starch. Cassava leaves are also widely consumed as a vegetable for protein, vitamins, and minerals (Berry 1993; Dahniya et al. 1994). Crop roots have gained industrial importance as a source of raw materials using in production of ethanol, flour for production of bread, and glucose syrup. The starch is using in the food industry in many preparations including sauces,

\footnotetext{
* Correspondence: said_abohesham@yahoo.com

${ }^{2}$ Horticultural Crops Technology Department, National Research Centre, Dokki, Giza, Egypt

Full list of author information is available at the end of the article
}

gravies, mustard powder, baby foods, and tapioca products such as puddings, glucose production, and some kind of bakery products (IITA 1990). As food, feed, and its promising industrial markets, there is an increasing focuses on cassava by governments, research, and development institutes in Africa (FAO 2004). Cassava is cultivated as annual crop in wide areas of tropical and subtropical countries for its edible starchy tuberous roots as a major source of carbohydrates (Kenneth 2011). The crop is a low cost production and is one of the cheapest foods (Shams 2011). It seems that the markets for cassava as a substitute of wheat flour and as a source in animal feed are expanded. Although considerable efforts were previously conducted by Egyptian researches to introduce cassava plants as a new non-traditional crop and enhance its productivity (El-

\section{Springer Open}

(C) The Author(s). 2020 Open Access This article is licensed under a Creative Commons Attribution 4.0 International License, which permits use, sharing, adaptation, distribution and reproduction in any medium or format, as long as you give appropriate credit to the original author(s) and the source, provide a link to the Creative Commons licence, and indicate if changes were made. The images or other third party material in this article are included in the article's Creative Commons licence, unless indicated otherwise in a credit line to the material. If material is not included in the article's Creative Commons licence and your intended use is not permitted by statutory regulation or exceeds the permitted use, you will need to obtain permission directly from the copyright holder. To view a copy of this licence, visit http://creativecommons.org/licenses/by/4.0/. 
Fieshawy 1986; Mansour 1992; Sherif et al. 2003; Nagwa et al. 2007; Nagwa 2008; Neama et al. 2016), the cultivated area of cassava is still so limited. In response to continuous interest for cassava cultivation in Egypt, new cultivars have to introduce to our farmers after their evaluation in newly reclaimed lands. It can be cultivated in newly reclaimed lands where cassava plants need little attention once they get established, then support its productivity by using foliar spraying of several additives of nutrients sources (Neama et al. 2016). Indeed, cassava realizes its high yield potential when it is supplied with adequate irrigation and nutrients. Therefore, cassava plants have tremendous future in Egypt, where its flour can be mixed with wheat flour at a ratio about $15 \%$ for bread making (Mansour 1992; Sherif et al. 2003; Nagwa et al. 2007). Also, we can depend on its rich starch as a cheapest alternative raw material source for many industrial products (El-Fieshawy 1986; Nagwa 2008; Neama et al. 2016). For this reason, we are seeking to introduce and evaluate new cassava cultivars to know suitable one for Egyptian conditions and to set practical recommendations for sustain and expand cassava cultivation in Egypt as a food industrial crop. It is well known that chemical fertilizers may not keep pace with time in maintaining the soil health and its sustainability. Also, the overuse of chemical fertilizers is detrimental to the environment and human health (Arisha and Bardisi 1999). The conventional use of chemical fertilizer can increase the yield but its inordinate use has negative effects on product quality, environment pollution, public health, and economical losses (Najm et al. 2011). On the other hand, the universe is going now on the way of minimizing pollution sources and using safe agriculture. The essential rates of amino acids are well known as safe means to enhance plant productivity and improve product quality (Awad et al. 2007). Thus, the foliar application of amino acids may contribute to enhance cassava productivity by improving plant growth under newly reclaimed lands (Neama et al. 2016). The current study is aiming to evaluate two cassava varieties: American and Brazilian types and improve the productivity of cassava plants by using foliar application of bio-stimulants, i.e., glutamine, lysine and active dry yeast, as foliar applications.

\section{Materials and methods}

Two field experiments were carried out in the experimental station of the National Research Centre (Research and Production Station, El-Nubaria region, El-Behira Governorate, Egypt). The experiments were conducted during the two successive seasons of 2016/2017 and 2017/2018 to study the effect of foliar application of different biostimulants treatments: glutamine, lysine, and yeast on vegetative growth, yield, and quality of two cultivars of cassava plants: American and Brazilian cultivars.
Cassava plants were sprayed with the bio-stimulants treatments at three times during the growth period. The first one was applied after 45 days from seed planting. The second one was applied 2 weeks later from the first one. The third one was applied 2 weeks later from the second one. The experimental design was split plot design with three replicates. The two cultivars were in the main plots, and the foliar application of bio-stimulants treatments randomly distributed in the sub plots.

Cassava was planted on 26 April during the two growing seasons of 2016/2017 and 2017/2018. Cassava stalks of similar thickness of approximately $2.5-3.0 \mathrm{~cm}$ in diameter were cut into stalk cuttings of $25-30 \mathrm{~cm}$ in length and planted vertically by burring two thirds of the cuttings into the soil and keeping one third of them over ground, then irrigated directly after planting. The standard agricultural practices were carried out uniformly in all treatment plots as recommended, wherever they were necessary. Twenty cubic meter of organic manure and $500 \mathrm{~kg}$ calcium super phosphate $\left(15.5 \% \mathrm{P}_{2} \mathrm{O}_{5}\right)$ per feddan $\left(4200 \mathrm{~m}^{2}\right)$ were added during land preparation through the ditches before planting, and ditches were covered by soil. Drip irrigation lines were used and spread over the ditches. Also, $250 \mathrm{~kg}$ ammonium sulphate $(20.5 \% \mathrm{~N})$ as a source of nitrogen and $200 \mathrm{~kg}$ potassium sulphate $(48 \%$ $\mathrm{K}_{2} \mathrm{O}$ ) as a source of potassium as recommended doses for cassava were added for all experimental plots. The total amounts of nitrogen and potassium fertilizers were divided into four equal doses. Fertilization program started at the fourth week after planting, and then other doses were monthly applied.

Both amino acids (glutamine and lysine) were obtained as commercial chemical substances from El-Gomhorya Company (Egypt). The pure dry yeast powder was activated by using sources of carbon and nitrogen with the ratio of 6: 1 to get the highest vegetative production of yeast. It allowed yeast cells to be grown and multiplied efficiently during conductive aerobic and nutritional conditions to produce beneficial bio constituents, i.e., phytohormones, carbohydrates, proteins, amino acids, fatty acids, vitamins, enzymes, and minerals, and hence allowed such constituents to release out of yeast cells in readily form. Such technique for yeast preparation based on nutritional media of glucose and casein as favorable sources of $\mathrm{C}, \mathrm{N}$, and other essential elements, i.e., $\mathrm{P}, \mathrm{K}$, $\mathrm{Ca}, \mathrm{Mg}, \mathrm{Fe}, \mathrm{Mn}, \mathrm{Cu}, \mathrm{B}$, and $\mathrm{Mo}$ as well as $\mathrm{Na}$ and $\mathrm{Cl}$ in suitable balance and adjusting incubation temperature (Barnett et al. 1990). Analysis of prepared yeast stock solution was total protein (5.3\%), total carbohydrates (4.7\%), N (1.2\%), P (0.13\%), K (0.3\%), Mg (0.013\%), Ca (0.02\%), Na (0.01\%); micro-elements (ppm), Fe (0.13), Mn (0.07), Zn (0.04), Cu (.04), B (0.016), Mo (0.0003), IAA $(0.5 \mathrm{mg} / \mathrm{ml})$, and $\mathrm{GA}(0.3 \mathrm{mg} / \mathrm{ml})$ according to Fathy et al. (2000). 


\section{Data recorded}

1- Vegetative growth parameters: Representative random samples of eight plants were labeled in each replicate for every treatment at 180 days after planting, and the following characters were recorded: Plant height, leaves number per plant, number of main stems and number of lateral branches, leaf area, and total chlorophyll content.

2- Tuber yield and yield components: The following data were recorded: Number of tubers per plant and tuber fresh weight, and root/shoot ratio were calculated according the following equation: Weight of tubers (g)/weight of shoot (g).

3- Tuber characters: The following data were recorded: Length and diameter of tubers and dry matter percentage of tubers.

4- Chemical composition of tubers: Starch percentage was determined as described by Smith and Zeeman (2006). Total carbohydrate percentage was determined colorimetrically as gram of glucose per $100 \mathrm{~g}$ dry weight of tubers according to the method of James (1995). Total fiber percentage of root tubers was determined as described by A.O.A.C. (1990). Nitrogen was determined in cassava tubers according to method of Horneck and Miller (1998). Phosphorus was determined colorimetrically, and potassium was determined using flame photometer according to the method of Page et al. (1982).

\section{Statistical analysis}

The treatment effects were evaluated by analysis of variance. The differences among treatment mean values were compared using Duncan's multiple range test at $P$ $<5 \%$ as reported by Gomez and Gomez (1984).

\section{Results \\ Vegetative growth characters \\ Effect of cultivars}

Data in Table 1 shows that the two different cassava varieties have significant variations in their vegetative growth parameters, i.e., plant height, leaves number, main stems, lateral branches, leaf area, and chlorophyll content in both growing seasons. The highest values of vegetative growth parameters were related to American cultivar, while Brazilian cultivar produced lower amounts of growth characters. These results were true during both growing seasons.

\section{Effect of bio-stimulants applications}

Vegetative growth parameters in relation to foliar application of bio-stimulants, glutamine, lysine, and active dry yeast, are presented in Table 1. Generally, the application of glutamine, lysine, and active dry yeast had significant responses on vegetative growth parameters, i.e., plant height, number of leaves and main stems per plant, lateral branches per plant, leaf area, and chlorophyll content. Whereas, the highest amounts of all vegetative growth characters were recorded by foliar sprayed treatment of glutamine at $200 \mathrm{mg} / \mathrm{L}$. On the contrary, foliar application of active dry yeast at rate of $2 \mathrm{~g} / \mathrm{L}$ resulted in the lowest amounts of all growth characters. These findings were true during the two growing seasons.

\section{Effect of the interaction between cultivars and bio- stimulants applications}

The interaction effects of two cassava cultivars and some bio-stimulants treatments showed significant variations at level of $5 \%$ during both growing seasons (Table 1). Whereas, the highest amounts of the vegetative growth parameters of cassava plants are found by using American cassava cultivar with foliar spray of glutamine at the rate of $200 \mathrm{mg} / \mathrm{L}$. On the contrary, the lowest amounts of vegetative growth parameters of cassava plants were recorded by Brazilian cassava cultivar with foliar application of yeast at the rate of $2 \mathrm{~g} / \mathrm{L}$. These results were true in the both growing seasons.

\section{Tuber yield and tuber characters Effect of cultivars}

Data in Table 2 clearly shows that cassava cultivars have significant effects on total tuber yield and tuber characters of cassava plants in both growing seasons. Whereas, the highest values of all vegetative growth parameters were found by American cassava cultivar. Conversely, the lowest vegetative growth parameters were recorded by using Brazilian cassava cultivar. These results were true during both growing seasons.

\section{Effect of bio-stimulants applications}

The measured data of tuber yield and its quality in relation to foliar application treatments by biostimulants, glutamine, lysine, and active dry yeast, were presented in Table 2. Generally, application of bio-stimulants had significant effects on the total tuber yield and tuber quality, i.e., tubers number per plant, tuber shoots ratio, tuber length, tuber diameter, and dry matter during the two growing seasons. Furthermore, the highest value of tuber yield and yield parameter were obtained by the foliar application of glutamine at a rate of $200 \mathrm{mg} / \mathrm{L}$. On the contrary, the lowest amount of tuber yield and yield parameter was found by foliar spray treatment of active dry yeast at $2 \mathrm{~g} / \mathrm{L}$. These findings were true in the two growing seasons. 


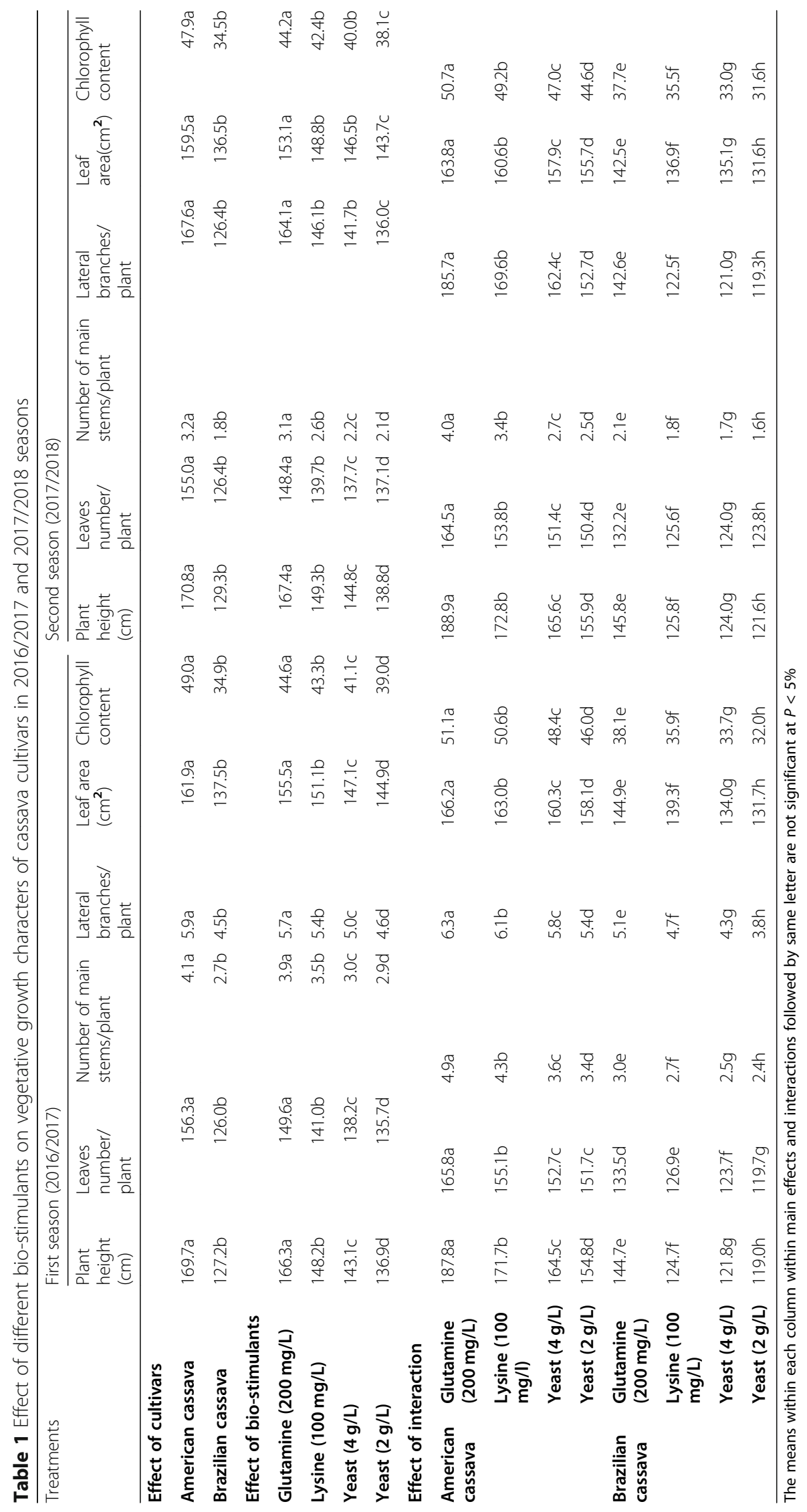


Table 2 Effect of different bio-stimulants on tuber yield and tuber characters of Cassava cultivars in 2016/2017 and 2017/2018 seasons

\begin{tabular}{|c|c|c|c|c|c|c|c|c|c|c|c|c|c|}
\hline \multirow{2}{*}{\multicolumn{2}{|c|}{ Treatments }} & \multicolumn{6}{|c|}{ First season $(2016 / 2017)$} & \multicolumn{6}{|c|}{ Second season (2017/2018) } \\
\hline & & $\begin{array}{l}\text { Tubers } \\
\text { number/ } \\
\text { plant }\end{array}$ & $\begin{array}{l}\text { Tuber } \\
\text { weight } \\
\text { (g) }\end{array}$ & $\begin{array}{l}\text { Tuber/ } \\
\text { shoot } \\
\text { ratio }\end{array}$ & $\begin{array}{l}\text { Tuber } \\
\text { length } \\
(\mathrm{cm})\end{array}$ & $\begin{array}{l}\text { Tuber } \\
\text { diameter } \\
(\mathrm{cm})\end{array}$ & $\begin{array}{l}\text { Dry } \\
\text { matter } \\
(\%)\end{array}$ & $\begin{array}{l}\text { Tubers } \\
\text { number/ } \\
\text { plant }\end{array}$ & $\begin{array}{l}\text { Tuber } \\
\text { weight } \\
\text { (g) }\end{array}$ & $\begin{array}{l}\text { Tuber/ } \\
\text { shoot } \\
\text { ratio }\end{array}$ & $\begin{array}{l}\text { Tuber } \\
\text { length } \\
(\mathrm{cm})\end{array}$ & $\begin{array}{l}\text { Tuber } \\
\text { diameter } \\
\text { (cm) }\end{array}$ & $\begin{array}{l}\text { Dry } \\
\text { matter } \\
(\%)\end{array}$ \\
\hline \multicolumn{14}{|c|}{ Effect of cultivars } \\
\hline \multicolumn{2}{|c|}{ American cassava } & 13.9a & $321.2 \mathrm{a}$ & $2.14 a$ & $35.9 a$ & $4.4 a$ & $36.6 a$ & $13.7 a$ & 320.3a & $2.25 a$ & $38.7 a$ & $4.5 \mathrm{a}$ & $35.5 a$ \\
\hline \multicolumn{2}{|c|}{ Brazilian cassava } & $11.3 b$ & $277.3 b$ & $1.73 b$ & $26.2 b$ & $2.9 \mathrm{~b}$ & $30.4 b$ & $10.7 b$ & $282.4 b$ & $1.91 \mathrm{~b}$ & $31.1 \mathrm{~b}$ & $2.9 \mathrm{~b}$ & $29.9 b$ \\
\hline \multicolumn{14}{|c|}{ Effect of bio-stimulants } \\
\hline \multicolumn{2}{|c|}{ Glutamine (200 mg/L) } & $13.6 a$ & $316.0 \mathrm{a}$ & $2.04 a$ & $34.8 a$ & $4.1 \mathrm{a}$ & $36.2 a$ & $13.4 a$ & $315.1 \mathrm{a}$ & $2.20 \mathrm{a}$ & $38.1 a$ & $4.1 \mathrm{a}$ & $35.0 a$ \\
\hline \multicolumn{2}{|c|}{ Lysine (100 mg/L) } & $12.5 b$ & $308.1 b$ & $2.01 \mathrm{~b}$ & $32.0 \mathrm{~b}$ & $3.8 b$ & $34.4 b$ & $12.3 b$ & $307.2 b$ & $2.17 a$ & $35.9 \mathrm{~b}$ & $3.8 \mathrm{~b}$ & $33.2 \mathrm{~b}$ \\
\hline \multicolumn{2}{|c|}{ Yeast (4 g/L) } & $12.3 c$ & $288.8 c$ & $1.86 c$ & $29.9 c$ & $3.6 d$ & $33.1 \mathrm{c}$ & $11.9 c$ & $294.9 c$ & $2.00 \mathrm{~b}$ & $33.6 c$ & $3.5 c$ & $32.0 \mathrm{~b}$ \\
\hline \multicolumn{2}{|c|}{ Yeast $(2 \mathrm{~g} / \mathrm{L})$} & $12.0 \mathrm{~d}$ & $283.6 \mathrm{~d}$ & $1.84 d$ & $27.7 c$ & $3.4 c$ & $30.4 d$ & $11.1 d$ & $288.1 d$ & $1.97 \mathrm{~b}$ & $32.1 d$ & $3.3 \mathrm{~d}$ & $30.4 c$ \\
\hline \multicolumn{14}{|c|}{ Effect of interaction } \\
\hline \multirow[t]{4}{*}{$\begin{array}{l}\text { American } \\
\text { cassava }\end{array}$} & $\begin{array}{l}\text { Glutamine } \\
\text { (200 mg/L) }\end{array}$ & $14.8 \mathrm{a}$ & $332.7 a$ & $2.28 a$ & 39.3a & $4.8 \mathrm{a}$ & $39.1 a$ & $14.6 a$ & $331.8 \mathrm{a}$ & $2.41 a$ & $41.4 a$ & $4.9 a$ & $38.0 \mathrm{a}$ \\
\hline & $\begin{array}{l}\text { Lysine } \\
(100 \mathrm{mg} / \mathrm{L})\end{array}$ & $13.8 \mathrm{~b}$ & $327.1 \mathrm{~b}$ & $2.25 b$ & $35.8 \mathrm{~b}$ & $4.5 b$ & $37.3 b$ & $13.6 \mathrm{~b}$ & $326.2 b$ & $2.38 a$ & $40.4 b$ & $4.6 b$ & $36.2 \mathrm{~b}$ \\
\hline & $\begin{array}{l}\text { Yeast }(4 \mathrm{~g} / \\
\text { L) }\end{array}$ & $13.6 \mathrm{c}$ & $313.8 \mathrm{c}$ & $2.03 c$ & $34.9 c$ & $4.3 c$ & $36.0 c$ & $13.4 c$ & $312.9 c$ & $2.12 \mathrm{~b}$ & $36.9 c$ & $4.2 \mathrm{c}$ & $34.9 c$ \\
\hline & $\begin{array}{l}\text { Yeast }(2 \mathrm{~g} / \\
\mathrm{L})\end{array}$ & $13.2 d$ & $311.2 d$ & $1.99 d$ & $33.7 d$ & $4.2 d$ & $33.8 d$ & $13.0 \mathrm{~d}$ & $310.3 d$ & $2.09 \mathrm{~b}$ & $36.0 d$ & $4.1 \mathrm{~d}$ & $32.7 d$ \\
\hline \multirow[t]{4}{*}{$\begin{array}{l}\text { Brazilian } \\
\text { cassava }\end{array}$} & $\begin{array}{l}\text { Glutamine } \\
\text { (200 mg/L) }\end{array}$ & $12.4 \mathrm{e}$ & 299.3e & $1.79 \mathrm{e}$ & $30.3 e$ & $3.3 e$ & $33.2 \mathrm{e}$ & $12.2 \mathrm{e}$ & $298.4 \mathrm{e}$ & $1.98 \mathrm{c}$ & $34.8 \mathrm{e}$ & $3.2 \mathrm{e}$ & $32.1 \mathrm{e}$ \\
\hline & $\begin{array}{l}\text { Lysine } \\
(100 \mathrm{mg} / \mathrm{L})\end{array}$ & $11.1 f$ & $289.1 f$ & $1.77 f$ & $28.2 f$ & 3.0f & $31.4 f$ & $10.9 f$ & $288.2 f$ & $1.96 c$ & $31.4 f$ & $3.0 f$ & $30.3 f$ \\
\hline & $\begin{array}{l}\text { Yeast }(4 \mathrm{~g} / \\
\text { L) }\end{array}$ & $11.0 \mathrm{~g}$ & $263.8 \mathrm{~g}$ & $1.69 \mathrm{~g}$ & $24.8 \mathrm{~g}$ & $2.8 \mathrm{~g}$ & $30.2 \mathrm{~g}$ & $10.4 \mathrm{~g}$ & $276.9 \mathrm{~g}$ & $1.87 d$ & $30.2 \mathrm{~g}$ & $2.8 \mathrm{~g}$ & $29.1 \mathrm{~g}$ \\
\hline & $\begin{array}{l}\text { Yeast }(2 \mathrm{~g} / \\
\mathrm{L})\end{array}$ & $10.8 \mathrm{~h}$ & $255.9 h$ & $1.68 \mathrm{~h}$ & $21.6 \mathrm{~h}$ & $2.6 \mathrm{~h}$ & $26.9 \mathrm{~h}$ & $9.2 \mathrm{~h}$ & $265.9 h$ & $1.84 d$ & $28.1 \mathrm{~h}$ & $2.5 \mathrm{~h}$ & $28.1 \mathrm{~h}$ \\
\hline
\end{tabular}

The means within each column within main effects and interactions followed by same letter are not significant at $P<5 \%$

\section{Effect of the interaction between cultivars and bio- stimulants applications}

The obtained results of the interaction effects between the different cultivars and the different bio-stimulants recorded significant variations at $5 \%$ level (Table 2) in the two growing seasons. Whereas, American cassava cultivar recorded the highest tuber yield and tuber yield quality when foliar sprayed by glutamine at the rate of $200 \mathrm{mg} / \mathrm{L}$ in both growing seasons. On the contrary, the lowest amounts of tuber yield and tuber quality parameters of cassava plants were found by using foliar application of active dry yeast at $2 \mathrm{~g} / \mathrm{L}$ with Brazilian cassava cultivar during both growing seasons.

\section{Chemical contents}

\section{Effect of cultivars}

The presented data in Table 3 shows that cassava varieties have significant effects on chemical contents, i.e., starch, total carbohydrates, total fibers, N, P, and
$\mathrm{K}$ (\%) of cassava tubers in both growing seasons. American cassava cultivar recorded the higher values of starch, total carbohydrates, N, P, and $\mathrm{K}$, while Brazilian cassava cultivar gave the lowest values of starch, total carbohydrates, N, P, and K. No significant differences between the two cultivars concerning their effects on the value of total fibers. These results were true during the two growing seasons.

Effect of bio-stimulants applications

Data of the measured chemical contents, i.e., starch, total carbohydrates, total fibers, N, P, and $\mathrm{K}(\%)$ in cassava tubers as affected by application of different biostimulants are presented in Table 3. Generally, the foliar application of glutamine at the rate of $200 \mathrm{mg} / \mathrm{L}$ had the highest values of starch, total carbohydrates, $\mathrm{N}, \mathrm{P}$, and $\mathrm{K}$ (\%) during the two growing seasons. Total fibers were increased by foliar application of lysine at the rate of $100 \mathrm{mg} / \mathrm{L}$. On the contrary, the lowest values of all chemical contents, i.e., starch, total carbohydrates, total 
Table 3 Effect of different bio-stimulants on chemical contents of tuber roots of Cassava cultivars in 2016/2017 and 2017/2018 seasons

\begin{tabular}{|c|c|c|c|c|c|c|c|c|c|c|c|c|c|}
\hline \multirow{2}{*}{\multicolumn{2}{|c|}{ Treatments }} & \multicolumn{6}{|c|}{ First season $(2016 / 2017)$} & \multicolumn{6}{|c|}{ Second season (2017/2018) } \\
\hline & & $\begin{array}{l}\text { Starch } \\
(\%)\end{array}$ & $\begin{array}{l}\text { Total } \\
\text { carbohydrates } \\
(\%)\end{array}$ & $\begin{array}{l}\text { Total } \\
\text { fibers (\%) }\end{array}$ & $\begin{array}{l}N \\
(\%)\end{array}$ & $\mathrm{P}(\%)$ & K (\%) & $\begin{array}{l}\text { Starch } \\
(\%)\end{array}$ & $\begin{array}{l}\text { Total } \\
\text { carbohydrates } \\
\text { (\%) }\end{array}$ & $\begin{array}{l}\text { Total } \\
\text { fibers (\%) }\end{array}$ & $\begin{array}{l}N \\
(\%)\end{array}$ & $\mathrm{P}(\%)$ & K (\%) \\
\hline \multicolumn{14}{|c|}{ Effect of cultivars } \\
\hline \multicolumn{2}{|r|}{ American cassava } & $50.8 a$ & $62.4 a$ & $2.3 a$ & $0.89 a$ & $0.29 a$ & $1.03 a$ & 49.8 a & $59.0 a$ & $2.4 a$ & $0.95 a$ & $0.31 a$ & $1.02 \mathrm{a}$ \\
\hline \multicolumn{2}{|r|}{ Brazilian cassava } & $46.1 \mathrm{~b}$ & $56.5 b$ & $2.5 \mathrm{a}$ & $0.68 b$ & $0.24 b$ & $0.77 \mathrm{~b}$ & $39.0 \mathrm{~b}$ & $47.5 b$ & $2.5 a$ & $0.70 \mathrm{~b}$ & $0.21 b$ & $0.78 b$ \\
\hline \multicolumn{14}{|c|}{ Effect of bio-stimulants } \\
\hline \multicolumn{2}{|c|}{ Glutamine (200 mg/L) } & $49.7 a$ & $62.4 a$ & $2.4 b$ & $0.88 \mathrm{a}$ & $0.28 a$ & $1.00 \mathrm{a}$ & 48.7 a & $57.4 a$ & $2.5 b$ & $0.96 a$ & $0.29 a$ & $0.98 a$ \\
\hline \multicolumn{2}{|c|}{ Lysine (100 mg/L) } & $48.1 \mathrm{~b}$ & $60.2 b$ & $2.5 a$ & $0.83 b$ & $0.26 b$ & $0.97 \mathrm{~b}$ & $47.1 \mathrm{~b}$ & $55.2 b$ & $2.6 a$ & $0.84 b$ & $0.27 b$ & $0.90 \mathrm{~b}$ \\
\hline \multicolumn{2}{|c|}{ Yeast (4 g/L) } & $44.6 c$ & $58.4 \mathrm{C}$ & $2.4 \mathrm{c}$ & $0.74 c$ & $0.23 c$ & $0.84 c$ & $43.1 \mathrm{C}$ & $51.5 \mathrm{c}$ & $2.5 b$ & $0.78 \mathrm{c}$ & $0.24 b$ & $0.88 b$ \\
\hline \multicolumn{2}{|c|}{ Yeast $(2 \mathrm{~g} / \mathrm{L})$} & $40.5 d$ & $57.3 d$ & $2.3 d$ & $0.69 d$ & $0.21 d$ & $0.81 d$ & $38.8 d$ & $48.8 d$ & $2.4 \mathrm{c}$ & $0.74 d$ & $0.22 c$ & $0.82 \mathrm{C}$ \\
\hline \multicolumn{14}{|c|}{ Effect of interaction } \\
\hline \multirow[t]{4}{*}{$\begin{array}{l}\text { American } \\
\text { cassava }\end{array}$} & $\begin{array}{l}\text { Glutamine } \\
\text { (200 mg/L) }\end{array}$ & $54.2 \mathrm{a}$ & $65.4 a$ & $2.2 f$ & $0.97 a$ & $0.33 a$ & $1.11 \mathrm{a}$ & $53.1 \mathrm{a}$ & $63.4 a$ & $2.4 d$ & $1.10 a$ & $0.34 a$ & $1.09 a$ \\
\hline & $\begin{array}{l}\text { Lysine (100 } \\
\mathrm{mg} / \mathrm{L})\end{array}$ & $53.1 \mathrm{~b}$ & $63.0 \mathrm{~b}$ & $2.3 d$ & $0.92 \mathrm{a}$ & $0.31 b$ & $1.06 \mathrm{~b}$ & $52.0 \mathrm{~b}$ & $60.2 b$ & $2.4 d$ & $0.94 b$ & $0.32 b$ & $1.07 a$ \\
\hline & Yeast (4 g/L) & $49.7 c$ & $60.8 c$ & $2.4 c$ & $0.85 b$ & $0.28 \mathrm{c}$ & $0.99 c$ & $48.6 \mathrm{c}$ & $57.8 \mathrm{c}$ & $2.4 d$ & $0.91 b$ & $0.29 c$ & $1.00 \mathrm{c}$ \\
\hline & Yeast (2 g/L) & $46.5 d$ & $60.4 d$ & $2.4 \mathrm{C}$ & $0.81 b$ & $0.26 d$ & $0.96 c$ & $45.4 \mathrm{~d}$ & $54.4 d$ & $2.4 d$ & $0.86 c$ & $0.27 d$ & $0.91 d$ \\
\hline \multirow[t]{4}{*}{$\begin{array}{l}\text { Brazilian } \\
\text { cassava }\end{array}$} & $\begin{array}{l}\text { Glutamine } \\
\text { (200 mg/L) }\end{array}$ & $45.3 e$ & $59.4 \mathrm{e}$ & $2.6 b$ & $0.79 c$ & $0.23 e$ & $0.88 d$ & $44.2 \mathrm{e}$ & $51.4 \mathrm{e}$ & $2.6 b$ & $0.81 \mathrm{c}$ & $0.24 \mathrm{e}$ & $0.86 \mathrm{e}$ \\
\hline & $\begin{array}{l}\text { Lysine (100 } \\
\mathrm{mg} / \mathrm{L})\end{array}$ & $43.2 f$ & $57.4 f$ & $2.7 a$ & $0.74 c$ & $0.21 f$ & $0.87 d$ & $42.1 \mathrm{f}$ & $50.1 f$ & $2.7 a$ & $0.74 d$ & $0.22 f$ & $0.80 f$ \\
\hline & Yeast (4 g/L) & $39.6 \mathrm{~g}$ & $56.1 \mathrm{~g}$ & $2.4 \mathrm{c}$ & $0.63 d$ & $0.19 \mathrm{~g}$ & $0.68 \mathrm{e}$ & $37.5 \mathrm{~g}$ & $45.2 \mathrm{~g}$ & $2.5 \mathrm{C}$ & $0.64 \mathrm{e}$ & $0.19 \mathrm{~g}$ & $0.75 \mathrm{~g}$ \\
\hline & Yeast (2 g/L) & $34.5 \mathrm{~h}$ & $54.3 \mathrm{~h}$ & $2.2 \mathrm{e}$ & $0.56 \mathrm{e}$ & $0.17 \mathrm{~h}$ & $0.65 \mathrm{e}$ & $32.1 \mathrm{~h}$ & $43.2 \mathrm{~h}$ & $2.3 e$ & $0.61 e$ & $0.17 \mathrm{~h}$ & $0.72 \mathrm{~g}$ \\
\hline
\end{tabular}

The means within each column within main effects and interactions followed by same letter are not significant at $P<5 \%$

fibers, $\mathrm{N}, \mathrm{P}$, and $\mathrm{K}(\%)$ of cassava tubers were recorded by foliar spray of active dry yeast at rate of $2 \mathrm{~g} / \mathrm{L}$. These findings were true in the two growing seasons.

\section{Effect of the interaction between cultivars and bio- stimulants applications}

The interaction treatments between the two cassava cultivars and different bio-stimulants foliar applications recorded significant variations concerning their effects on chemical contents of cassava tubers at 5\% level in the two growing seasons (Table 3). American cassava cultivar produced the highest values of starch, total carbohydrates, N, P, and K (\%) when foliar sprayed by glutamine at the rate of $200 \mathrm{mg} / \mathrm{L}$ during the two growing seasons. The highest contents of total fibers were found in cassava tubers of Brazilian cultivar when foliar sprayed by lysine at rate of $100 \mathrm{mg} / \mathrm{L}$. On the contrary, the lowest amounts of all chemical contents, i.e., starch, total carbohydrates, total fibers, $\mathrm{N}, \mathrm{P}$, and $\mathrm{K}(\%)$ in cassava tubers were related to Brazilian cultivar and foliar application of active dry yeast at rate of $2 \mathrm{~g} / \mathrm{L}$. These results were true in both growing seasons.

\section{Discussion}

Our obtained results reported that American type of cassava is the most suitable under Egyptian condition, which ranked the first in all vegetative growth characters, tuber yield, tuber quality, and chemical composition, with foliar sprayed by glutamine at a rate of 200 $\mathrm{mg} / \mathrm{L}$. It could be attributed by the genetic variations between the different cultivars, i.e., American and Brazilian cultivars. It is well known that the actual performance of any cultivar depends on its genetic parameters interacted with all surrounded environmental conditions (Saleh et al. 2018). The obtained variations between American and Brazilian cultivars in vegetative characters are mainly due to the genotype of each cultivar. This may be due to high demand toward assimilation of vegetative growth phase and may affect tuber production. Therefore, the highest plant productivity can be achieved by using suitable cultivar and application of the best management of all agricultural practices. The management and sustainable cultural practices are highly needed and must be preferable. For instance, the foliar application of amino acids may contribute to enhance plant productivity and improve product quality (Takeuchi et al. 2008; 
Mazher et al. 2011). The enhancement effects for amino acids due to their positive role protein assimilation and plant metabolism, which important for cell formation, and consequently increase growth and dry matter. Glutamic could enhance plant growth and plant development by its effect on gibberellins biosynthesis. Glycine and glutamic acids are fundamental metabolites in the process of vegetable tissues and chlorophyll synthesis. Moreover, the amino acid of glutamic acts as a cytoplasm osmotic agent of the guard cell and regulate opening of the stomata (Abdel-Mawgoud et al. 2011). These increases in the above mentioned data due to this amino acid "Glutamine" can directly or indirectly influence the physiological activities of cassava productivity. The regulatory effect of amino acids on growth could be explained by the notion that some amino acids can affect plant growth and development through their influence on gibberellins biosynthesis. Also, amino acids may play an important role in plant metabolism and protein assimilation which is necessary for cell formation and consequently increase in fresh and dry matter. Similarly, significant positive effects of amino chelate fertilizers on plant growth and yield have also been reported by several previous works (Machado et al. 2008; Datir et al. 2012; Ghasemi et al. 2013, 2014; Sadak et al. 2015; Fahimi et al. 2016; Souri and Yarahmadi 2016).

Bio-stimulants are composed of single- or multiingredient plant extracts containing hormones, enzymes, proteins, amino acids, vitamins, microelements, and other biologically active compounds (Basak 2008). Biostimulants affect plant metabolism when applied in small quantities through stimulation of natural hormone synthesis and activity, enhancement of nutrients uptake, stimulation of root growth, and increase of resistance to unfavorable conditions. The multiple functions of biostimulants have induced many researchers to investigate such effects on crops (Fawzy et al. 2010; Paradikovic et al. 2011; Neama et al. 2016). The dose of biostimulants, time and way of application, crop species or cultivar, growth conditions, and other environmental factors can affect the bio-stimulant action. Foliar application of bio-stimulants can be treated as systemic agents, so they must successfully penetrate the cuticle to reach active sites in the plant tissues.

El- Shabasi et al. (2005) reported that foliar spraying of garlic plants with mixture of glaycine, alanin, cysteine, and arginine (each at $100 \mathrm{ppm}$ ) gave the highest plant height, leaf blade area, neck and bulb diameter, fresh weight of leaves, and markedly produced higher total yield as well as crude protein. Shaheen et al. (2013) found that foliar spraying by amino mix compound caused an enhancement in onion plant growth characters, i.e., length of plant, leaves number, and fresh and dry weight of plant. Also, bulb yield and TSS recorded their highest values when amino mix sprayed at level within $2-3 \mathrm{~cm} / \mathrm{L}$. El- Zohiri and Asfour (2009) reported that foliar applications of amino acids at $0.25 \mathrm{ml} / \mathrm{L}$ enhanced vegetative growth parameters, i.e., plant height and dry matter of potato plants. Amino acids are the fundamental ingredients for the process of protein synthesis. Other several authors reported that the foliar application of amino acids enhanced plant growth, yield, and improve product quality (Kamar and Omar 1987 on cucumber; Karuppaiah et al. 2000 on potato; Awad et al. 2007 on potato). Kamar and Omar (1987) mentioned that amino acids are widely used for biosynthesis of non-protein nitrogenous compounds such as coenzymes, vitamins, pigments, purine, and pyrimidine bases.

More attention was focused for minimization of environmental pollution and its impacts on human health through reducing chemical fertilizers in plant production (FAO/TTC 2001). According to Sarojnee et al. (2009), amino acids can improve fertilizer assimilation, increase uptake of nutrients and water, enhance the photosynthetic rate and dry matter partitioning, and hence increase yield and quality. Paradikovic et al. (2011) found that the application of bio-stimulants could be considered as a good production strategy for obtaining high yields of nutritionally valuable vegetables with lower impact on the environment. Amino acids are well known as bio-stimulants that have positive effects on plant growth, yield, and significantly mitigate the injuries caused by abiotic stresses (Kowalczyk and Zielony 2008). Furthermore, amino acids are also used to alleviate the negative effects of some environmental stress, e.g., salinity (Neeraja et al. 2005; Tantawy et al. 2009; AbdelMawgoud et al. 2011).

However, in response to continue interest for cassava cultivation and entrepreneurship, new cultivars should introduce to the farmers after several on-farms evaluation in different locations to know their actual performance under preferable management of all agricultural practices.

\section{Conclusion}

The American type of cassava is the most suitable under Egyptian conditions, which recorded the highest vegetative growth characters, tuber yield, tuber quality, and chemical composition, with foliar application of glutamine at a rate of $200 \mathrm{mg} / \mathrm{L}$.

\section{Abbreviations}

N: Nitrogen; P: Phosphorus; K: Potassium; g/L: Gram per liter

\section{Acknowledgements}

This work was funded by National Research Centre, Egypt (Project ID

10120206), which is gratefully acknowledged. Authors extend sincere thanks to all staff at the Research and Production Station in El-Nubaria for their assistance during carrying out of this investigation. 


\section{Authors' contributions}

This work is a combined effort of all of the authors. NM Hassan and NA Marzouk designed this work, conducted the field experiments, and performed the chemical analysis of the samples. ZF Fawzy and SA Saleh wrote the manuscript and revised it. All authors read and approved the final manuscript.

\section{Funding}

This work was supported by project titled: Cultivation and production of cassava for the production of starch and cassava flour as a partial substitute for wheat crop (ID. 10120206) funded National Research Centre, Egypt.

\section{Availability of data and materials}

The datasets generated and/or analyzed during the current study are included in this published study.

\section{Ethics approval and consent to participate}

Not applicable.

\section{Consent for publication}

Not applicable.

\section{Competing interests}

The authors declare that they have no competing interests.

\section{Author details}

'Vegetable Research Department, National Research Centre, Dokki, Giza, Egypt. ${ }^{2}$ Horticultural Crops Technology Department, National Research Centre, Dokki, Giza, Egypt.

Received: 19 February 2020 Accepted: 8 April 2020

Published online: 21 April 2020

\section{References}

A.O.A.C. (1990) Official methods of analysis. Association of Official Agriculture Chemists, 15th edn. USA, Washington DC

Abdel-Mawgoud AM, El-Bassiouny AM, Ghoname AA, Abou-Hussein SD (2011) Foliar application of amino acids and micronutrients enhance performance of green bean crop under newly reclaimed land conditions. Australian Journal of Agricultural Research 5(6):459-469.

Abdullahi N, Sidik JB, Ahmed OH, Zakariah MH (2014) Effect of planting methods on growth and yield of cassava (Manihot esculenta Crantz) grown with polythene-covering. J. Exp. Bio. \& Agr. Sci (1):1

Arisha HM, Bardisi A (1999) Effect of mineral and organic fertilizers on growth, yield and tuber quality of potato under sandy soil conditions. Zagazig J. Agric. Res. 26(2):391-405

Awad EM, Abd El-Hameed AM, El-Aimin ZA (2007) Effect of glycine, lysine and nitrogen fertilizer rates on growth, yield and chemical composition of potato. J. Agric. Sci. Mansoura Univ. 32(10):8541-8551

Barnett JA, Payne RW, Yarrow D (1990) Yeasts, characteristics and identification. $2^{\text {nd }}$ Ed. Cambridge University Press, London, 999 pp 39(2):26-32

Basak A (2008) Biostimulators. Definitions, classification and legislation. University Press, London, $999 \mathrm{pp}$

Berry SS (1993) Socio-economic aspects of cassava utilization and use in Africa: implications for the development of appropriate technology. COSCA Working Paper No. 8. Collaboratory Study of Cassava in Africa, IITA, Ibadan

Dahniya MT, Akoroda MO, Alvarez MN, Kaindaneh PM, Ambe Tumanteh J, Okeke JE, Jalloh A (1994) Development and dissemination of appropriate root crops packages to farmers in Africa. In (Ofori F, Hahn SK eds.) Proceedings of the Ninth Symposium of the International Society of Tropical Root and Crops, pp. 2-9. 20-26 October 1991. ISTRC, Wageningen

Datir RB, Apparao BJ, Laware SL (2012) Application of amino acid chelated micronutrients for enhancing growth and productivity in chili (Capsicum annum L.). Plant Sci. Feed 2:100-105

El-Fieshawy MA (1986) Evaluation of some agronomic characters related to growth and yield of cassava (Manihot esculenta Crantz). Ph.D. Thesis, Fac. Agric., Moshtohor, Zagazig Univ. Banha-Branch, Egypt

El-Shabasi MS, Mohamed SM, Mahfouz SA (2005) Effect of foliar spray with amino acids on growth, yield and chemical composition of garlic plants. The $6^{\text {th }}$ Arabian Conf. for Hort. Ismailia, Egypt.
El-Zohiri SM, Asfour YM (2009) Effect of some organic compounds on growth and productivity of some potato cultivars. Annals of Agric.Sci. Moshtohor 47(3):403-415

Fahimi F, Souri MK, Yaghobi F (2016) Growth and development of greenhouse cucumber under foliar application of Biomin and Humifolin fertilizers in comparison to their soil application and NPK. Iran J Sci Technol Greenhouse Cult 7:143-152

FAO (2004) The Global Cassava Development Strategy and Implementation Plan, Volume 1. Proceedings of the Validation Forum on the Global Cassava Development Strategy. Rome 26-28

FAO/TTC (2001) World markets for organic fruits and vegetables: opportunities for developing countries in the production and export of organic horticultural products, TC/D/Y1669E/9.01/6730

Fathy S, Lei S, Farid E-DS (2000) Induce cold tolerance of outdoor tomatoes during early season by using triphosphate (ATP), yeast, other natural and chemical treatments to improve their fruiting and yield. J. Agric. Sci. Mansoura Univ. 25(1):377-401

Fawzy ZF, El-Bassiony AM, Behairy AG, Helmy YI (2010) Effect of foliar spraying by some bio and organic compounds on growth, yield and chemical composition of snap bean plants. Journal of Applied Sciences Research 6(12): 2269-2274

Ghasemi S, Khoshgoftarmanesh AH, Afyuni M, Hadadzadeh H (2013) The effectiveness of foliar applications of synthesized zinc-amino acid chelates in comparison with zinc sulfate to increase yield and grain nutritional quality of wheat. Eur J Agron 45:68-74

Ghasemi S, Khoshgoftarmanesh AH, Afyuni M, Hadadzadeh H (2014) Iron (II)amino acid chelates alleviate salt-stress induced oxidative damages on tomato grown in nutrient solution culture. Sci Hortic 165:91-98

Gomez KA, Gomez AA (1984) Statistical procedures for agricultural research, 2nd edn. John Wiley \& Sons, Inc., New York

Horneck DA, Miller RO (1998) Determination of total nitrogen in plant tissue. In: Kalra YP (ed) Handbook of references methods for plant analysis. CRC Press, Boca Raton, pp 75-83

IITA (1990) Cassava in tropical Africa: a reference manual. In: International Institute of Tropical Agriculture. Ibadan, Nigeria, p 176

James CS (1995) Analytical chemistry of foods. Blackie Academic and Professionals. London 256-257

Kamar ME, Omar A (1987) Effect of nitrogen levels and spraying with aminal-forte (amino acids salvation on yield of cucumber and potatoes. J. Agric. Sci. Mansoura Univ. 12(4):900-907

Karuppaiah PK, Manivonnar MV, Sriramach A, Kuppusamy G (2000) Responses of cucumber to foliar application of nutrients on light mine spoil. J. of the Indian Society of soil Science 49(1):150-153

Kenneth VR (2011) Evaluation of three cassava varieties for tuber quality and yield. Gladstone Road Agri. Cent, Cro

Kowalczyk K, Zielony T (2008) Effect of amino plant and Asahi on yield and quality of lettuce grown on rockwool. Conf. of biostimulators in modern agriculture, 7-8 Febuary 2008, Warsaw, Poland

Machado F, Alves RE, Fiqueiredo RW (2008) Application of 1-methylcyclopropene, calcium chloride and calcium amino acid chelate on fresh-cut cantaloupe muskmelon. Pesqui Agropecu Bras 43:569-574

Mansour SA (1992) Physiological studies on cassava plant. Ph.D. Thesis, Fac. Agric. , Cairo Univ., Egypt

Mazher AM, Zaghloul SM, Mahmoud SA, Siam HS (2011) Stimulatory effect of kinetin, ascorbic acid and glutamic acid on growth and chemical constituents of Codiaeum variegatum L. plants. Am. Eurasian J. Agric. Environ. Sci. 10:318-323

Nagwa MH (2008) Improvement of productivity and quality of cassava (Manihot esculenta (rantz) in newly reclaimed lands using some mineral and biofertilization treatments in relation to plant density. Ph.D. Thesis, Fac. Agric., Ain Shams Univ., Egypt

Nagwa MH, Safaa AM, Ragab ME (2007) Performance of cassava plant under different plant densities and potassium levels in newly reclaimed lands. J. Agri. Sci., Suez Canal Univ 7(2):81-91

Neama MM, Nagwa MH, Saleh SA, Tantawy AS (2016) Enhancement of cassava productivity in Egyptian new reclaimed lands by using different foliar application treatments. Int. J. of PharmTech Research 9(12):204-214

Neeraja G, Reddy IP, Gautham B (2005) Effect of growth promoters on growth and yield of tomato cv. Marutham. Journal of Research ANGRAU 33(3):68-70 
Page AL, Miller RH, Keeney DR (1982) Methods of soil analysis. American Society of Agronomy, Inc. Soil Science Society of America, Inc. Publisher Madison Wisconsin USA

Paradikovic N, Vinkovic T, Vinkovic Vrcek I, Zuntar I, Bojic M, Medic M (2011) Effect of natural biostimulants on yield and nutritional quality: an example of sweet yellow pepper (Capsicum annuum L.) plants. Sci. Food Agric. 91:2146-2152

Sadak M, Abdoelhamid MT, Schmidhalter U (2015) Effect of foliar application of aminoacids on plant yield and some physiological parameters in bean plants irrigated with sea water. Acta Biol Colomb 20:141-152

Saleh S, Liu G, Liu M, Ji Y, He H, Gruda N (2018) Effect of irrigation on growth, yield, and chemical composition of two green bean cultivars. Horticulturae 4(1):3

Sarojnee DY, Navindra B, Chandrabose S (2009) Effect of naturally occurring amino acid stimulants on the growth and yield of hot peppers (Capsicum annum L.). Journal of Animal \& Plant Sciences 5(1):414-424

Shaheen AM, Rizk FA, Sawan OM, Bakry MO (2013) Sustaining the quality and quantity of onion productivity throughout complementarity treatment between compost tea and amino acids. Middle East J. Agric. Res. 2(4):108-115

Shams A (2011) Combat degradation in rain fed areas by introduction new drought tolerance crops in Egypt. Intl. J. Wat. Res \& Arid Env. 1(5):318-325

Sherif SA, Ibrahim ST, Atallal RA (2003) Effect of phosphorus and potassium fertilizer rates and intercropping cassava plants with squash on land equivalent ratio growth, yield components and yield of cassava plants in Toshky region. Proceeding of the conference "the Future of African food security" Inst. of African Res. \& Studies. Cairo Univ., Egypt, 24-25 June: pp. 24-41

Smith AM, Zeeman SC (2006) Quantification of starch in plant tissues. Nature Protocols 1:1342-1345. https://doi.org/10.1038/nprot.2006.232

Souri MK, Yarahmadi B (2016) Effect of aminochelates foliar application on growth and development of Marigold (Calendula officinalis) plants. Iran J Plant Prod Technol 15:109-119

Takeuchi M, Arakawa C, Kuwahara Y, Gemma H (2008) Effects of L-pro foliar application on the quality of 'Kosui' Japanese pear. Acta Hortic. 800:549-554

Tantawy AS, Abdel-Mawgoud AM, El-Nemr MA, Ghorra CY (2009) Alleviation of salinity effects on tomato plants by application of amino acids and growth regulators. European Journal of Scientific Research 30(3):484-494

\section{Publisher's Note}

Springer Nature remains neutral with regard to jurisdictional claims in published maps and institutional affiliations.

\section{Submit your manuscript to a SpringerOpen ${ }^{\circ}$ journal and benefit from:}

- Convenient online submission

- Rigorous peer review

- Open access: articles freely available online

- High visibility within the field

- Retaining the copyright to your article

Submit your next manuscript at $\boldsymbol{\nabla}$ springeropen.com 